\title{
CARCINOSARCOMA OF THE GALLBLADDER: CASE REPORT
}

\author{
Carcinossarcoma de vesícula biliar: relato de caso
}

José Marcos PARREIRA, Daniel Emílio Dalledone SIQUEIRA, Aline Moraes MENACHO, Lívia Lazzaretti PELIZZARI, Liliãn Cabral Pereira dos SANTOS

From the Department of General Surgery, Charity Hospital Santa Casa de Misericórdia de Curitiba, PR, Brazil.

\begin{abstract}
Correspondence:
Financial source: none

Conflicts of interest: none

Received for publication:

Accepted for publication:
\end{abstract}

Aline Moraes Menacho, e-mail: alinemenacho@yahoo.com.br

\section{INTRODUCTION}

Gallbladder cancers have incidence of 1.2 / 100,000 , being the adenocarcinoma the most common histologic type (88\%) 1 . The carcinosarcoma is the rarest form of cancer of the gallbladder, with only 67 cases reported in the literature 10 . This tumor is composed of both malignant epithelial and mesenchymal origin in a mixed way².

\section{CASE REPORT}

Woman of 59 years referred cramping pain in right hypochondrium and epigastrium during two years accompanied by nausea and vomiting. Noticed painful mass in the right hypochondrium six months ago. She denied weight loss, comorbidities, smoking, or previous surgery. On physical examination, the patient was anicteric and afebrile with a movable mass, flat, painful, approximately $4 \mathrm{~cm}$ diameter in hypochondrium. Laboratory tests were within normal limits. Abdominal ultrasound demonstrated the presence of gall bladder with a mass measuring $4 \times 5 \times 4$ $\mathrm{cm}$ and a calculus of $0.8 \mathrm{~cm}$. Was performed conventional cholecystectomy without tumor invasion and lymph node involvement without the need for adjuvant chemotherapy. Histopathologic examination revealed a malignant neoplasm with areas of well-differentiated adenocarcinoma with papillary and tubular growth interspersed with areas of differentiated squamous cell carcinoma associated with condrossarcomatous osteoid and atypical tissues. The patient died six months after surgery due to multiple metastases.

\section{DISCUSSION}

In 1907, Karl Landsteiner described for the first case of carcinosarcoma of the gallbladder ${ }^{6}$. Since then, only 67 cases have been reported in the literature ${ }^{5}$.

The gallbladder carcinosarcoma is a tumor of mixed character, presenting epithelial and mesenchymal components ${ }^{2}$. Is generally an epithelial carcinoma, but there are also some cases with predominant cell carcinoma. The mesenchymal component is usually heterogeneous and can adduce cartilage, muscle and bone $^{3,10}$. Tavassoli9 suggests that only carcinossarcomas with muscle component should be considered true ones. Despite the efforts to understand the histogenesis, it remains uncertain. According to Weidner, a single stem cell components originate epithelial and mesenchymal cells. Another theory, however unlikely, is that a atypical connective tissue reaction induce the appearance of carcinosarcoma ${ }^{11}$. Some authors suggest that carcinoma and sarcoma come from different malignant clones, but interconnected ${ }^{4}$. A final hypothesis would explain the appearance of carcinosarcoma from the differentiation of conventional carcinoma ${ }^{3}$.

Carcinosarcoma of the gallbladder is more common in females, 4.3:1. Appears, usually after the sixth decade of life $^{3}$. Approximately $75 \%$ of patients with carcinosarcoma have associated cholelithiasis and the main symptoms are manifested as pain in the right upper quadrant, weight loss and itching ${ }^{8}$.

There are no specific tumor markers and conclusive imaging findings and it is very difficult to determine early lesions. Most patients are diagnosed with locally advanced disease (invasion of serosa) or distant metastasis, especially to the liver. Adrenal, pancreas and diaphragm can also be affected ${ }^{9}$.

The treatment consists basically of cholecystectomy, with or without expanded hepatic resection. There is no evidence demonstrating benefit in instituting chemotherapy and radiotherapy ${ }^{1,7,8}$.

The prognosis is poor with median survival of seven months. There is no difference in prognosis between the among histological types, but it is possible that tumor size is a determining factor in survival. Zhang et al. ${ }^{12}$ found that 12 tumors smaller than $5 \mathrm{~cm}$ provide median survival from 17 to 26 
months, while bigger ones reduce in 11 months the life expectancy. Uzun ${ }^{10}$ reported a case of a patient who had survival 54 months after carcinosarcoma diagnosis, the longest in the literature. In that case, the tumor was less than $3 \mathrm{~cm}$, was restricted to the lumen of the gallbladder without serosal and liver invasion ${ }^{10}$.

\section{CONCLUSION}

Little is known about the pathophysiology and treatment of carcinosarcoma of the gallbladder, and there are no records of permanent cure of this tumor. Also there is no knowledge about specific markers and imaging studies that have good awareness of this neoplasm. Consequently, the later the diagnosed worse is the prognosis.

\section{REFERENCES}

1. Ajiki T, Nakamura T, Fujino $Y$, Suzuki $Y$, Takeyama $Y, K u Y$, Kuroda $Y$, Ohbayashi C.. Carcinosarcoma of the gallbladder with chondroid differentiation. J Gastroenterol 2002; 37 (11): 966-971.

2. Agarwal $T$, Jain $M$, Goel $A$, Visayaragavan $P$, Gupta RK. Carcinosarcoma of the gallbladder. Indian J Pathol Microbiol 2009; 52 (2): $244-245$.
3. Hotta $T$, Tanimura $H$, Yokoyama S, Ura K, Yamaue H. So-called carcinosarcoma of the gallbladder; spindle cell carcinoma of the gallbladder: report of a case. Surg Today 2002; 32 (5): 462-467.

4. Kawano R, Takeshima $Y$, Inai K. Alteration of the p53 gene of lung carcinomas with sarcomatous transformation (spindle cell carcinoma): analysis of four cases. Pathol Int 1996; 46 (1): 38-45.

5. Kim MJ, Yu E, Ro JY. Sarcomatoid carcinoma of the gallbladder with a rhabdoid tumor component. Arch Pathol Lab Med 2003; 127 (10): 406-408.

6. Landsteirner K. Plattenepithelkarzinom und Sarkom der Gallenblase in einem falle von Cholelithiasis. Z Klin Med 1907; 62: 427-33.

7. Okabayashi T, Kobayashi M, Nishimori I, Namikawa T, Okamoto K, Onishi S, Araki K.. Adenosquamous carcinoma of the extrahepatic biliary tract: clinicopathological analysis of Japanese cases of this uncommon disease. J Gastroenterol 2005; 40 (2): 192-199.

8. Okabayashi T, Sun ZL, Montgomery RA, Hanazaki K. Surgical outcome of carcinosarcoma of the gall bladder: a Review. Worl J. Gastroenterol 2009; 15 (39): 4877-4882.

9. Tavassoli FA. Classification of metaplastic carcinomas of the breast. Pathol Annu 1992; 27 (2):89-119.

10. Uzun MA, Koksal N, Gunerhan Y, Celik A, Gunes P. Carcinosarcoma of the Gallbladder: Report of a Case. Surg Today 2009; 39 (2): 168-171.

11. Weidner N. Sarcomatoid carcinoma of the upper aerodigestive tract. Semin Diagon Pathol 1987; 4 (2):157-68

12. Zhang L, Chen Z, Fukuma M, Lee LY, Wu M. Prognostic significance of race and tumor size in carcinosarcoma of gallbladder: a metaanalysis of 68 cases. Int J Clin Exp Pathol 2008; 1 (1): 75-83. 